原著

\title{
若年者のめまい症例の臨床的検討
}

\author{
竹内 万彦・坂井田 寛
}

\section{A Clinical analysis of vertigo and dizziness in childhood and adolescence}

\author{
Kazuhiko Takeuchi, Hiroshi Sakaida \\ Department of Otorhinolaryngology, Head and Neck Surgery \\ Mie University Graduate School of Medicine
}

A study was conducted on children and adolescents complaining of vertigo, dizziness and equilibrium disturbance who were examined at the Department of Otorhinolaryngology of Mie University Hospital from August, 2000 to July, 2010. Of the 673 patients who visited our vertigo clinic, 22 (3.3\%) were 18 years of age or under. Their equilibrium and neurological status were examined. They consisted of 7 boys and 15 girls and their ages ranged from 5 to 18. Of the 22 patients, 9 had orthostatic dysregulation, 8 had peripheral vestibular disorders and 3 had benign paroxysmal vertigo of childhood. In the vestibular diseases of peripheral origin, there were Ménière's disease, bilateral vestibular dysfunction, vestibular neuritis and large vestibular aqueduct syndrome. Regarding the characteristics of vertigo, 8 (35\%) complained of rotatory vertigo and 15 (65\%) non-rotatory vertigo. Eight (36\%) had some kind of hearing loss. The long term clinical course of a 5-year-old girl with Ménière's disease and the clinical course of 9-year-old girl with benign paroxysmal vertigo of childhood are explained in detail.

Key words: vertigo and equilibrium disturbance, children, adolescent

\section{はじめに}

小児および思春期のめまい疾患は成人のめまい 疾患と多くの面で異なる。疾患の種類についても 小児では起立性調節障害や小児良性発作性めまい が多く, 成人で頻度の高い良性発作性頭位めまい 症は小児では少ない。また, 小児はめまいの性状 を正確に訴えることに限界があるため，患児の協 力が得られずに十分な検査ができないことも多 い。今回われわれの施設で過去10年間に経験した 小児と思春期のめまい症例について臨床的検討を

三重大学大学院医学系研究科耳鼻咽喉 - 頭頸部外科
加え, 若干の知見を得たので報告する。

\section{対象および方法}

2000年 8 月から 2010 年 7 月に三重大学医学部附 属病院耳鼻咽喉・頭頸部外科めまい外来を受診し た18歳以下の症例を対象とした。めまい外来を受 診する患者はあらかじめ一般外来で最初の診察を 受ける。ここで耳鼻咽喉科的診察と直立検査, 偏 倚検査, 眼振検査 (注視, 頭位, 頭位変換眼振) などの平衡機能検査と標準純音聴力検査を施行 し，精査が必要と考えられた場合にめまい外来を 受診する仕組みになっている。めまい外来では, 電気眼振計記録下に, 温度刺激検査, 視標追跡検 


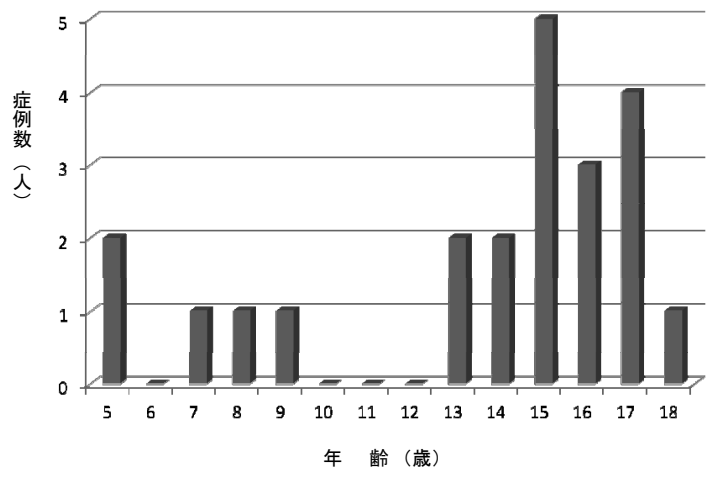

図1若年者のめまい症例の年齢分布

査, 視運動性眼振検査を行った。起立性調節障害 の診断は, 大国の診断基準による問診1) とシェロ ング検査を行い, 起立性調節障害 (OD) 診断基 準 ${ }^{1)}$ に基づいて行った。また, 必要に応じて側頭 骨 CT 検査を行った。

\section{結果}

2000年 8 月から 2010 年 7 月に三重大学医学部附 属病院耳鼻咽喉・頭頸部外科めまい外来を受診し た18歳以下の患者は22名（男児 7 名, 女児 15 名） であり,これらを解析の対象とした。これはこの 期間に当科めまい外来を受診した全めまい症例 673例の3. $3 \%$ に相当した。

小児・思春期のめまい症例の年齢分布を図 1 に 示した。最小年齢は 5 歳であった。10歳から 12 歳 までの症例はなかった。

めまいの性状は, 7 名 $(32 \%)$ が回転性めまい, 残る14名（64\%）は非回転性めまいであった。1 名は回転性, 非回転性の両方を訴えた。非回転性 めまいの訴えとしては, 立ちくらみ, 物が傾いて 見える，目の前が真っ暗になる，頭がぐらぐらす る，気を失った感じ，ふらつき，ファーとする， 前に倒れこむ, 景色が歪んで見える, 焦点が合わ ないなどがあった。

8 名（36\%）に難聴が認められた。一側低音障 害型感音難聴が 3 例, 両側混合性難聴が 2 例, 両 側高度感音難聴, 一側高度感音難聴, および一側 機能性難聴がそれぞれ 1 例であった。 $20^{\circ} \mathrm{C}, 5$ $\mathrm{ml}, 20$ 秒刺激による温度刺激検査では，5例に 一側 CPが，4例に両側 CP が認められた（9／ $21,41 \%)$ 。なお, 最大緩徐相速度が $10^{\circ} /$ 秒以下 の場合に CP と判定した。

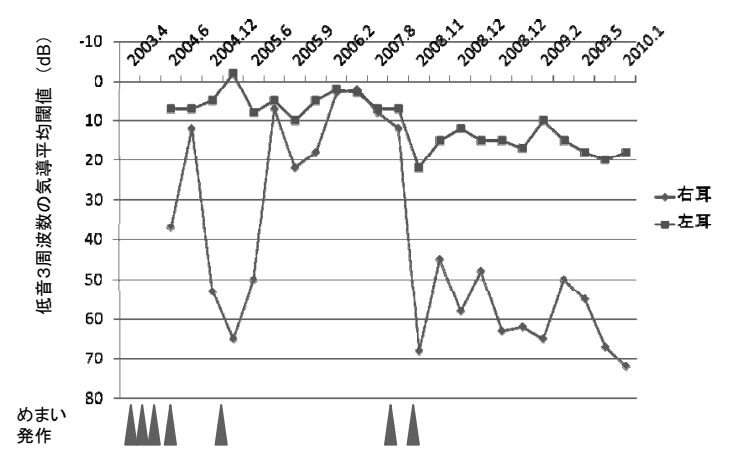

図 2 症例 1 の聴力の推移とめまい発作の状況

診断は，起立性調節障害が 9 例 $(41 \%)$ ，末梢 前庭性めまいが 8 例 $(36 \%)$, 小児良性発作性め まいが 3 例, そして小脳失調 1 例, 心因性めまい 1 例，原因不明が 2 例であった（ 1 人で複数の診 断がなされた症例がある)。末梢前庭性めまいの 内訳は, メニエール病 1 例, 両側前庭機能高度低 下 1 例, 前庭神経炎 1 例, 前庭水管拡張症 1 例, その他 4 例であった。起立性調節障害 9 名のうち 8 名は 13 歳以上であり, 13 歳以上の患者 17 名中の $47 \%$ を占めた。一方, 9 歳以下の患者 5 名の中で 起立性調節障害が原因であったのは 1 名 (20\%) であった。 9 歳以下の 5 例中 4 例は末梢前庭性め まいであった。

回転性めまいを訴えた 8 例のうち 5 例（63\%） に何らかの難聴がみられた。これに対して, 非回 転性めまいを訴えた15例のうち難聴がみられたの はわずかに 3 例 $(20 \%)$ であった。これは，非回 転性めまいを訴えた症例に起立性調節障害が多い ためであった。起立性調節障害 9 例中 7 例 $(78 \%)$ が非回転性めまいを訴えた。これに対して末梢前 庭性めまいの症例 8 例では回転性めまい 4 例, 非 回転性めまい 4 例であった。また, 起立性調節障 害と最終診断された 9 例のうち難聴がみられたの

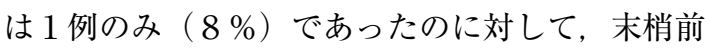
庭性めまいでは 8 例のうち 6 例に（75\%）に難聴 がみられた。

次に長期間経過観察できた小览のメニエール病 症例について詳述する。なお,この症例の初期の 状況は紹介元の小児科医により短報 ${ }^{2)}$ として報告 されている。

症例 $1 ： 5$ 歳女児（発症時） 
周波数 $(\mathrm{Hz})$

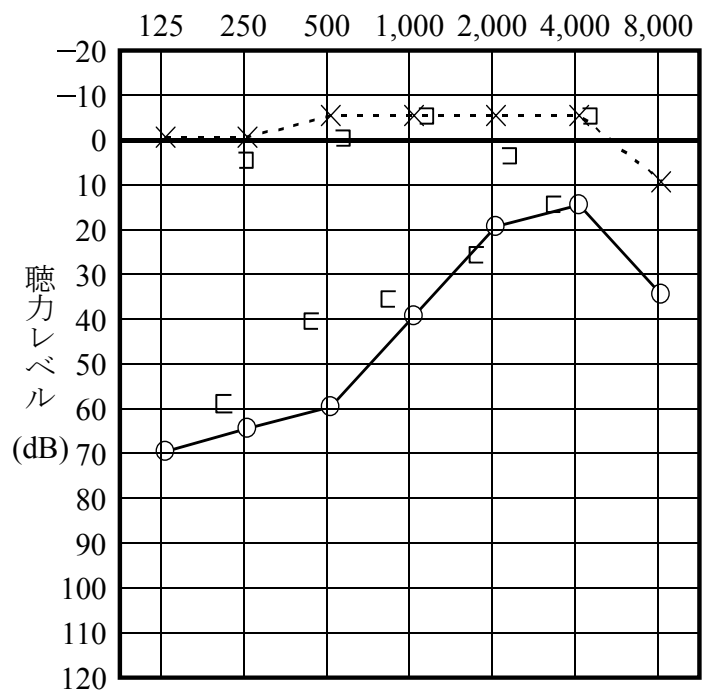

図3 症例 1 の標準純音聴力検査所見 (2005年 5 月)

\section{主訴：嘔吐}

既往歴，家族歴：特になし

現病歴：2003年 4 月ごろより 8 時間ほど持続す る嘔吐と腹痛が週に 1 回から月に 1 回ほどの頻度 で起こるようになった。その 1 年後, 嘔吐の前に 頭が摇れるような感覚を母親に訴えるようになっ た。回転性めまいであることが耳鼻咽喉科医によ り確認された。めまい発作時には嘔吐と後頭部痛 も出現し，歩けなくなった。めまいの持続時間は 数時間のことが多かった。めまい発作時に右耳の 難聴を自覚したが，耳鳴はなかった。2004年 6 月 のめまい外来受診時の平衡機能検査では，ロンベ ルグ検査は陰性, 足踏検査は正常範囲であり, 自 発眼振, 注視眼振, 頭位眼振, 頭位変換眼振はみ られなかった。温度刺激検査 $\left(20^{\circ} \mathrm{C}, 5 \mathrm{ml}, 20\right.$ 秒刺激の少量注入法）では最大緩徐相速度が右 $0^{\circ}$ /秒，左 $16^{\circ} /$ 秒であった。視運動性眼振検査お よび視標追跡検査は正常であった。側頭骨 CT で は外リンパ瘦を疑わせる迷路気腫や前庭水管拡大 を含め奇形はみられなかった。当科受診後の聴力 の推移とめまい発作を図 2 に示した。2005年 5 月 の時点では中・低音域の感音難聴がみられた（図 3 )。イソソルビドの投与を開始したのち聴力は 改善し回転性めまい発作は生じなくなった
周波数 $(\mathrm{Hz})$

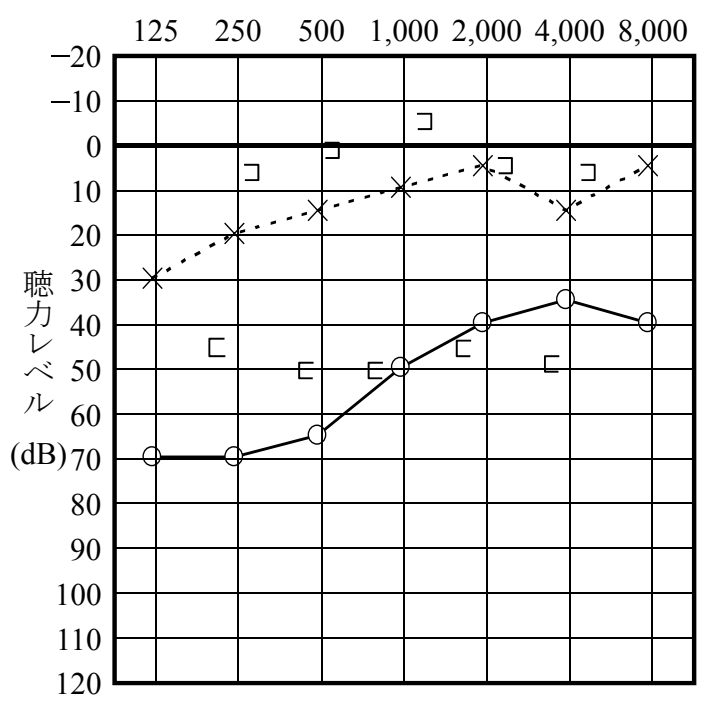

図4 症例 1 の標準純音聴力検査所見 (2008年11月)

が，2007年 8 月から再びめまい発作が出現し左聴 力も悪化した（図 4 )。このため, 現在はイソソ ルビドを中止し，水分摂取療法 ${ }^{3)}$ を行い経過観察 している。

次に小览良性発作性めまいに起立性調節障害が 合併した患者について述べる。

症例 $2: 9$ 歳女览 (発症時)

主訴：回転性めまい

家族歴, 既往歴 : 特になし

現病歴：2010年 4 月ころより, 左側頭部の拍動 性頭痛を伴い，前触れなく 1 ～60分持続する回転 性めまいとふらつきがおこるようになった。6月 の一般外来受診までにこのような発作が 7 回あっ た。めまい発作時には母親によって眼振が観察さ れたが，詳細は不明であった。また，朝自宅で起 き上がれない，学校でも気分不快となり保健室で 休むことも多いなどの訴えもあった。長時間にわ たるピアノの練習のストレスを強く感じていた。 患者本人は毎日のピアノの練習が長く苦痛と訴 え，手を怪我して練習を休んでいるときにはめま いが減少することなどから心因の関与が考えられ た。

当科初診時には神経学的所見, 聴力, および平 衡機能検査では, 特に異常が認められなかった。 
血圧，脈拍は安静仰臥位には 87/50 mmHg, 78 回/分, 立位直後には 87/68 mmHg, 104回/分, 立位10分後には 80/63 mmHg, 91回/分であり, 起立性調節障害の診断基準 ${ }^{1)}$ に合致した。そのた め起立性調節障害と小览良性発作性めまいと診断 し，ミドドリン (メトリジン $\left.{ }^{\circledR}\right) 4 \mathrm{mg}$ とシプロヘ プタジン塩酸塩（ペリアクチン ${ }^{\circledR} ） 4 \mathrm{mg}$ の投与を 開始した。その後, 一時経過良好であったが, 頭 痛とめまいが再発し制御できなくなり, ロメリジ ン塩酸塩（ミグシス ${ }^{\circledR}$ ) の投与を開始した。治療 開始後13か月でめまいと頭痛はほぼ消失した。現 在は特に薬剤は服用していない。

本症例ではめまいの発症に心因の関与が考えら れた。このほかにも心因の関与が疑われた症例が 3 例あった。起立性調節障害の診断に合致した 13 歳の男児においては同級生（男児）の中にさまざ まな悪口を言う子がいたためにストレスを感じて いた。また, 父親が厳しかったため, 入院させた ところめまいは軽減した。16歳の女児では母親が 4 つ上の兄を優遇し自分と差別する, 母親は大学 への進学を望んでいるが自分は行きたくないと訴 えた。17歳の男児ではバドミントンのラケットが 右耳に当たってからめまいと右側の感音難聴が生 じた。聴性脳幹反応は正常で, 瘦孔症状はなく内 耳機能検査も正常で外リンパ瘦も否定的であり, めまいの諸検査でも特に異常は認められず，心因 性難聴を伴う心因性めまいと考えられた。

\section{考察}

今回の検討では, 起立性調節障害が 9 例と最も 多く, 続いて未梢性前庭障害が 8 例であった。田 中ら ${ }^{4)}$ のめい・平衡障害の主訴で受診した 1 歳〜18歳の 41 例を対象とした検討では起立性調節 障害が最多で, 急性小脳失調症と多発性硬化症が 続いたと報告されている。藤井ら ${ }^{5)}$ もまい・平 衡障害を訴えて受診した小児98名を検討し, 起立 性調節障害が全体の $42.9 \%$ を占めて最多で, 内耳 性めまいが $26.5 \%$ ，中枢性めまいが $17.3 \%$ あっっ たと報告している。われわれの検討でも起立性調 節障害は全体の $41 \%$ を占め, これらの報告と一致 していた。9歳以下では末梢前庭性めまいが多 く, 13歳以上では起立性調節障害が多かった。10 歳から12歳まではそのはざまであるために患者が いなかったと推定される。

今回の検討では, 中枢性めまいは小脳失調の 1
例のみであった。これは初診時に小脳症状や第 8 脳神経以外の脳神経症状のある患者は中枢性めま いの疑いで他科紹介となり，当科のめまい外来に 回らなかったためと考えられる。めまいを訴える 小児を診察する際，てんかん，脳腫瘍，急性小脳 失調症などは忘れてはならない疾患 ${ }^{6)}$ である。側 頭葉てんかんの19\%にめまいが随伴することか ら，小児のめまいでは全例に脳波検査が必要とさ れるとの報告もある7)。めまいを伴う側頭葉てん かんの特徵は, 発作時に意識消失や思考中の意識 の変容を認めることである。腹部の不快感を伴う ことも多い7)。めまい・平衡障害を主訴として受 診した 1 歳〜18歳の41例を対象とした検討におい て，急性小脳失調症が41例中 9 例 $(22 \%)$ と高率 にみられたとの報告もある(4)。

上述した症例 1 は 5 歳で発症した小児のメニエ ール病症例である。メニエール病の有病率は人口 10万人あたり 35 万人程度であり ${ }^{8)}$, 好発年齢は 平均 40 50歳代である。近年高齢化の傾向があ

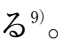

小児のメニエール病がメニエール病全体に占め る割合は， $0.4 \sim 7 \%$ と報告者によって若干異な るものの，いずれも低率である ${ }^{10)}$ 。今回の検討で は，同時期に経験した成人のメニエール病が 651 例中45例であったので, 小児の占める割合は $2.1 \%$ （1／46）であった。また，小児のめまい患者に 占めるメニエール病の割合は， 0 〜 4 と報告さ れているが(10), 今回の検討では $4.5 \%$ （22例中 1 例）であった。

小児のメニエール病の特徵として, めまいとと もに片頭痛を訴えることが多い，めまい発作持続 時間が短い，聴力障害も軽度で回復することが多 いことがあげられる市。しかしながら難治性であ

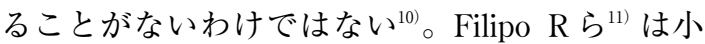
児メニエール病に対する第一選択薬として利尿剤 を挙げている。われわれも症例 1 に対してはまず イソソルビドを用いた。しかしめまい発作は制御 できたものの聴力が改善せず，イソソルビドは中 止した。長期的に良好な聴力予後が得られるとさ れている水分摂取療法3) を行って経過観察中であ る。

一般的にメニエール病は, 発症後 $2 \sim 3$ 年程度 の経過で軽快する群と長期にわたって発作が反復 する重症群に二分されるといわれている ${ }^{8)}$ 。症例 
1 では発症から 5 年でめまい発作は消失したもの の, その後聴力が悪化し, 改善がみられておらず, 重症群に相当する。

さて，小児良性発作性めまい（benign paroxysmal vertigo of childhood）は近年小児のめまいの 原因として取り上げられることが多くなり ${ }^{122}$ ，ひ とつのトピック ${ }^{13)}$ となっている。小児良性発作性 めまいは良性反復性めまい (Benign recurrent vertigo，BRV）と表記されることがある ${ }^{13)}$ 。本疾患 は, Basser $\mathrm{LS}^{14)} に よ り$ 初めて記載された。小児 2165名を対象とした調査では, 45名が本疾患の診 断基準に合致し，頻度は $2.6 \%$ と高かった ${ }^{15)}$ 。

尾関ら ${ }^{16)}$ は20歳未満の131例の検討を行い, 小 児良性発作性めまいは15例（11\%）で，特に10歳 以下の 32 例に限ればその割合は $25 \%$ と高かったと 報告している。また，五島ら ${ }^{12)}$ は，小児のめまい 患者の中では小児良性発作性めまいが最多で，そ の平均年齢は7.6歳と従来の報告より若干高い傾 向が認められたと述べている。今回の検討では, 小児良性発作性めまいは22例中 3 例 $(14 \%)$ と少 なかった。

小児良性発作性めまいは, 国際頭痛分類第 2 版 ${ }^{17)}$ では, 一次性頭痛の中の片頭痛の中に含ま れ, 周期性嘔吐症, 腹部片頭痛とともに小児周期 性症候群としてまとめられている。

本疾患におけるめまいの責任病巣に関して詳細 は明らかになっていないものの, 尾関 ${ }^{13)}$ は, 末梢 の障害よりもむしろ中枢障害の関与がより強いと 述べている。一般の小児において片頭痛が認めら れる割合は $10.6 \%$ とされているのに対して小児良 性発作性めまいでは24\%に片頭痛があったという 報告があり ${ }^{15)}$ ，片頭痛と小児良性発作性めまいに は何らかの関連があるものと推定される ${ }^{15}$ 。

片頭痛に関連するめまいの発症機序について, 室伏 ${ }^{18)}$ は，(1)血管収縮による中枢または末梢前庭 の虚血，(2)拡延性抑制（spreading depression） による神経障害, (3)神経ペプチド放出による神経 や感覚器の障害などを挙げている。病態がはっき りしないため, 片頭痛に関連するめまいに対して も小児良性発作性めまいにおけると同様に確立さ れた治療法はない。ただし, ロメリジン塩酸塩を 10歳以下の片頭痛症例に試み有効であったとの報 告がある ${ }^{19)}$ 。また, 小児片頭痛の発作予防薬とし てシプロヘプタジンを勧める報告もある ${ }^{20)}$ 。シプ
ロヘプタジンが有効であるのは本薬が抗ヒスタミ ン作用のみならず，抗セロトニン作用，カルシウ ムチャンネルブロッカーとしての作用を持つため であり，比較試験は行われていないが，12歳以下 の小児では片頭痛の予防薬として広く使用されて いる ${ }^{20)}$ 。

ロメリジン塩酸塩は脳血管に対して選択的な血 管収縮抑制作用を示すカルシウム拮抗薬であり, 脳血流増加作用を有し，拡延性抑制に伴う脳血流 量の低下を抑制する。われわれは，症例 2 に対し てまずシプロヘプタジン塩酸塩 (ペリアクチン ${ }^{\circledR}$ ) を用い，次いでロメリジン塩酸塩（ミグシス ${ }^{\circledR}$ ) を使用することによって，めまいを制御すること ができた。

小児良性発作性めまいの予後は比較的良好で, 発症から 1 年以内に約 $60 \%, 3 \sim 4$ 年以内に約 $90 \%$ 症例においてめまいは消失するとされてい る ${ }^{21)}$ 。上述した症例 2 でも発症から約 1 年でめま い発作はほぼ消失した。しかし，小児良性発作性 めまいは単一の疾患ではないとの報告もある ${ }^{22) 。 ~}$

小児のめまいを考えるにあたってもう一つの重 要な点は心因の関与である。症例 2 でもピアノの 練習がストレスになっていたと推察される。前述 した13歳男児, 16歳女児, 17歳男児の 3 例も含 め, 22 例中 4 例で何らかの心因の関与が考えられ た。

栗原ら ${ }^{6}$ は, 小览のめまいでは疲労や睡眠不 足, 勉強や受験の不安, いじめ, 自己主張と親の 要求とのあつれきなどが原因となっていることが 多く, 児の体力, 知能, 性格, 生活習慣, 学校や 家庭の問題など，心理療法が主体となると述べて いる。また，関ら ${ }^{23)}$ は，小児心因性めまい・平衡 障害の 3 症例を報告し, その特徴として, 転倒し やすい, 起立・歩行障害が高度, 特に立ち直り反 射が悪いことなど，下肢の脱力を示唆する所見が 診断上, 非常に重要としている。小児良性発作性 めまいや片頭痛と診断された若年者では, 健常者 と比べて行動面や感情面の問題が多いと報告され ている ${ }^{24)}$ 。

以上のように若年者のめまい疾患は成人のめま い疾患と多くの面で異なる。若年者のめまい疾患 の診療にあたっては，起立性調節障害や小児良性 発作性めまいの頻度が多く，心因が関与すること も多いという若年者のめまいの特徵を理解の上, 
特別な配慮が必要である。

\section{まとめ}

1。過去10年に当科めまい外来で診療した若年 者のめまい症例22名について報告した。

2. 末梢前庭性めまい, 起立性調節障害, 小览 良性発作性めまいが多くみられた。

3. 5 歳女览のメニエール病症例と 9 歳女児の 小児良性発作性めまい症例について詳述した。

\section{文献}

1) 大国真彦：OD 診断基準と起立検査実地法. 市橋保雄，草川山治，鈴木 栄，他編．起立 性調節障害. 7-13頁, 中外医学社, 東京, 1974

2 ) Miyahara M, Hirayama M, Yuta A, et al.: Too young to talk of vertigo? Lancet 373:516, 2009

3 ) Naganuma H, Kawahara K, Tokumasu K, et al. : Water may cure patients with Meniere disease. Laryngoscope 116: 1455-1460, 2006

4) 田中学, 坂田英明：小児科領域におけるめ まい・平衡障害を主訴とする症例の検討. Equilibrium Res 57: 604-607, 1998

5 ）藤井恵子, 伊藤八次, 水田啓介, 他：小児の めまい・平衡障害の検討. Equilibrium Res 53: 374-380, 1994

6 ）栗原真紀子, 小西行雄 : 小児のめまい・ふら つき. JOHNS 18: 1251-1254, 2002

7 ) Busis SN: Vertigo. In ed Bluestone CD, Stool SE: Pediatric Otolaryngology Volume I. pp 261-270, WB Saunders, Philadelphia, 1983

8 ）前庭機能異常に関する調査研究班編：メニエ ール病診療ガイドライン, 金原出版, 東 京, 2011

9) Shojaku H, Watanabe Y, Yagi $T$, et al. Changes in the characteristics of definite Ménière's disease over time in Japan: a longterm survey by the peripheral vestibular disorder research committee of Japan, formerly the Ménière's disease research committee of Japan. Acta Otolaryngol 129: 155-160, 2009

10) Akagi $H$, Yuen $K$, Maeda $Y$, et al.: Ménière's disease in childhood. Int J Pediatr Otorhinolaryngol 61: 259-264, 2001

11) Filipo R, Barbara M: Juvenile Ménière's disease. J Laryngol Otol 99: 193-196, 1985
12）五島史行，守本倫子，大原卓哉，他：小児良 性発作性めまい症の臨床的特徵。日耳鼻会報 $114: 562-567,2011$

13）尾関英徳：小児良性発作性めまい一片頭痛に 関連した小览期特有のめまい症候群. Equilibrium Res 69: 445-447, 2010

14) Basser LS: Benign paroxysmal vertigo of children. Brain 87: 141-152, 1964

15) Abu-Arafeh I, Russell G: Paroxysmal vertigo as a migraine equivalent in children: a population-based study. Cephalalgia 15: 22-25, 1995

16）尾関英徳，岩崎真一，室伏利久：若年者のめ まい症例の検討一良性反復性めまい（Benign Recurrent Vertigo）を中心として一. Equilibrium Res 67: 194-199, 2008

17）国際頭痛学会・頭痛分類委員会 : 国際頭痛分 類第 2 版（ICHD-II）。 日頭痛会誌 $31 ： 13-$ 188, 2004

18）室伏利久：片頭痛性めまい一その病態の解明 にむけて。耳鼻・頭頸外科 $81 ： 737-745$, 2009

19）藤田光江：小览の片頭痛. 診断と治療 90 ： 883-887, 2002

20) Lewis DW, Winner P: The pharmacological treatment options for pediatric migraine: an evidence-based appraisal. NeuroRx 3: 181191, 2006

21) Drigo P, Carli G, Laverda AM: Benign paroxysmal vertigo of childhood. Brain Dev 23: 38-41, 2001

22) Krams B, Echenne B, Leydet J, et al.: Benign paroxysmal vertigo of childhood: long-term outcome. Cephalalgia 31: 439-443, 2011

23）関 聡, 犬飼賢也, 渡辺一道, 他 : 小览心 因性めまい・平衡障害の 3 症例. Equilibrium Res 63: 346-352, 2004

24) Reale L, Guarnera M, Grillo C, et al.: Psychological assessment in children and adolescents with Benign Paroxysmal Vertigo. Brain Dev 33: 125-130, 2011

利益相反に該当する事項はない。 